\title{
Writing and remembering frontier conflict: the rule of law in 1880s central Australia
}

\author{
Amanda Nettelbeck
}

\section{Introduction}

Frontier conflict has been a hotly contested issue in recent Australian historiography, particularly in the recent 'history wars' debate whose most public representatives have been seen to be the revisionist historian Professor Henry Reynolds on the one side, and the author and publisher Keith Windschuttle on the other. On both sides of this debate, the terms on which contemporary scholars can identity and document a history of frontier conflict have been discussed, asserted and challenged. For instance, the recent book Frontier conflict: the Australian experience, which arose from a forum held at the National Museum of Australia in December 2001, is an example of the controversies that arise around the very boundaries of historiography. ${ }^{1}$ In particular, controversy surrounds the methods by which, and extent to which, Aboriginal deaths in frontier conflict can be enumerated by contemporary historians, and the extent to which that conflict can be identified as warfare. That volume, which includes contributions from Reynolds, Windschuttle and another 13 scholars of Australian frontier history, is organised around a series of questions that address this issue in different ways: What happened? How do we know? How do we remember? How do we tell?

It is clear to all researchers of this area that the extent of frontier conflict and its status as documentable event - what happened and how do we know? - are amongst the most controversial questions in contemporary Australian historiography. ${ }^{2}$ Yet although undoubtedly important, these are not the only critical questions. Just as important in understanding the culture in which such events could arise are the other questions: how do we tell, and how do we remember? In a recent essay, Raymond Evans and Bill Thorpe identify this as the process of 'not simply attempting bodycounts' but 'attending thoughtfully to the atmosphere of acceptable terror which surrounded these disturbing episodes'. ${ }^{3}$ Firstly, then, in what terms was frontier conflict told? For example, how covert was its expression or, contrastingly, how openly was it acknowledged? Secondly, what echoes do those forms of telling leave, to resonate in contemporary social memory?

1. Attwood and Foster 2003.

2. For example, in Victoria, see Clark 1996.

3. Evans and Thorpe 2001: 31 . 


\section{The central Australian frontier}

A considerable focus of the 'history wars' debate has been the surreptitious nature of frontier conflict between settlers and Aboriginal people; deaths and other forms of social destruction are clearly difficult to quantify when they take a covert form, recorded on paper privately, euphemistically, or not at all. But, at different times and in certain contexts, conflict was amply recorded. Its reality is a key theme in hundreds of official documents written and sent between police officers, Protectors of Aborigines, colonial governors and colonial secretaries. In the first half of the nineteenth century, conflict was frequently discussed in such official documents as a pressing problem, both legal and ethical. Yet by the late nineteenth century, most of the Australian frontiers had receded and, in a confident mood of national consolidation, were being turned into the material of pioneer reminiscence. ${ }^{4}$ At such a time, when the notion of the 'active frontier' was becoming the theme of popular late-colonial adventure fiction, a contested frontier was just opening up in central Australia. ${ }^{5}$ In what terms was this later frontier imagined, administered and - in an official capacity - reported by those who 'made' it?

Mounted Constable William Willshire was Officer in Charge of the Native Police in the Centre from the time of the force's establishment in 1884 until his suspension from the police force on a charge of murder in 1891. A fellow officer who patrolled with the Native Police between 1884 and 1888 was Mounted Constable Erwin Wurmbrand. To a significant degree, these officers represented the authority of colonial law for the vast region around Alice Springs, reaching west into Arrernte country around the MacDonnell Ranges and south into Larinjka country. Both their names would become associated with a violent and legally flexible model of frontier policing. How did these policemen perceive their duty as monitors of the central Australian frontier and, in their records of patrols, how did they reconcile its violence in terms of the rule of law? As their official reports of the mid-1880s will show, they seemed to regard themselves as being at the spearhead of a special zone of warfare. This was not a zone of warfare openly declared as such, but nonetheless it was one in which a sense of strategic engagement with a recognisable enemy is openly and repeatedly articulated.

The term 'warfare' is, of course, amongst the most contested of terms to be argued over in the context of frontier historiography, not only because of its consequences for how we understand the national past, but also because of the dilemmas implicit in defining the terms that would justify its usage: what intent, what degree of political organisation, what scale does use of the term require? Yet 'warfare' may well be the best word to describe the mindset, as well as the tactics, employed on this, as on some of Australia's earlier colonial frontiers. ${ }^{6}$ In his recent book The Australian frontier wars, John Connor elaborates on the tactical dimensions of frontier conflict in early colonial Australia 'that can only be defined as "war"': settlers and soldiers fought Aboriginals with guns, and later, with horses and trackers, and Aboriginals fought settlers and soldiers with attacks on station property, cattle and homesteads. ${ }^{7}$ By the time of the

For the region of South Australia, see Foster et al. 2001.

See for instance Reid 1990, Rose 1991, Austin 1992, Kimber 1997, Wilson 2000.

See for instance Broome 1988.

Connor 2002: $x-x i$. 
Centre's expanding frontier military expeditions could not be conducted against Aboriginal people, who according to South Australia's proclamation were legally declared British subjects, but an assumed atmosphere of warfare is evident in the language, views and actions recorded in Willshire's and Wurmbrand's official reports of patrols of the 1880s. These reports illustrate that policing freedoms granted to those in charge of 'the rule of law' functioned on a discretionary basis - and, importantly, on an anticipatory basis - in the service of Aboriginal pacification.

That the police should perform this service seemed to be widely acknowledged, not just by an isolated and relatively unchecked officer like Willshire, but also by the pastoralist community whose interests he served during the later 1880s. This truth was prosaically summed up by one of the Centre's pastoralists, Robert Warburton, at the end of that decade. Any new stage of frontier expansion, he wrote, is 'difficult and will be until the blacks knuckle under - but not before - when you have subdued them you can be as kind as you like to them - its [sic] only the same old story of pioneer settlement over and over again since Australia was first settled by white men'. ${ }^{8}$

Willshire's reports of the mid to late 1880s enumerating Aboriginal fatalities (men shot dead often, seemingly, without an earnest attempt to make arrests and without warrants to do so) were received and filed without comment by the Sub-inspector of Police in Port Augusta, Brian Besley, and the Commissioner of Police, William Peterswald, in Adelaide. This suggests an implicit sanction in the early phase of the Centre's pastoral expansion by the police administration. When the deaths of three Aboriginal men during one of Willshire's early patrols around Powell's Creek in the further north apparently drew enquiries from the Adelaide-based Protector of Aborigines, Edward Hamilton, Willshire's superior officer Besley - also Sub-Protector of Aborigines - responded that the incident had 'occurred a long way beyond the boundary of any district'; that he considered it 'impossible for you to obtain the information from any other source [than Mounted Constable Willshire] for sometime to come'; and that these considerations would 'probably justify what would otherwise be considered irregular'. ${ }^{9}$ In other words, as the police historian Bill Wilson has argued, the history of the Centre's policing in this decade was not just one of individual but of 'institutionalised violence'. ${ }^{10}$ The role performed by the Native Police under men like Willshire and Wurmbrand was performed 'aggressively' and 'with minimal controls' ${ }^{11}$

During the decade of the 1880s, the Centre was a space of sparse white settlement and, relative to European presence, dense Aboriginal occupation. The Overland Telegraph Line had been completed in 1872 and now linked the continent from south to north. It was, as Daniel Headrick puts it, a 'tool of Empire' ${ }^{12}$ that in the coming decade would provide a departure point for exploration and pastoral expansion, and mark the beginning of permanent European settlement. ${ }^{13}$ Even so, in the early years of the $1880 \mathrm{~s}$ established pastoral stations were few and distantly scattered. Yet hopes for more

8. Warburton to Gordon, 22 May 1890, GRG 1/1/395/1890.

9. GRG 5/2/920/1888.

10. Wilson 1996: 71 .

11. Wilson 1996: 71 .

12. Headrick 1981.

13. Shepherd 1996: 44. 
extensive stocking of the Territory were strong. With the annexation of the Territory to South Australia in November 1863, 200,000 hectares of the region had been made open for lease, ${ }^{14}$ and since that time its stocking with cattle had increased several-fold. ${ }^{15}$

It was not only economic opportunity that the Centre presented. In 1877 the Hermannsburg mission had been established west of Alice Springs by Lutheran missionaries, who would, in the coming decade, prove to be a thorn in the side of the police. In all these senses, the Centre in the 1880 s was a space not yet 'arrived', in terms of an established colonial infrastructure. Yet a sense of its national potential was strong at this late point in the century, when the vision of nationhood was being clarified into a recognisable form for European Australians.

\section{The Native Police force}

By 1884 , the need for greater police protection for newly established settlers in the Centre was a clearly understood agenda. The handful of stocked stations that existed in the extensive country of the interior was by then familiar with Aboriginal retaliations on occupations of their country: ${ }^{16}$ at the Top End in September, four miners had been killed on the Daly River in a much publicised case of Aboriginal aggression, ${ }^{17}$ and two station employees were attacked at Anna's Reservoir and the homestead burned down. ${ }^{18}$ Throughout 1884 pastoral entrepreneurs had petitioned the Chief Secretary and the Commissioner of Police for greater police presence in the interior in order to check Aboriginals from 'making raids on the outlying cattle stations and spearing the cattle and horses'. ${ }^{19}$ Police support, to this end, was regarded as an economic necessity for the region's expansion: 'I would respectfully urge the immediate necessity of protection for the settlers', wrote one petitioner. 'The heavy expenses and risks of settling the northern Country are in themselves causes of anxiety - but this further danger ... is one which seriously retards progress. ${ }^{20}$ To the degree that 'benefit to the natives themselves' was considered in these petitions, it was done in the light of an understood frontier culture in which settlers take matters into their own hands and 'the natives are invariably the greatest sufferers'; ${ }^{21} \mathrm{a}$ 'sufficient display' of 'the force of law' would 'transform them into peaceable assistants in the occupation of the country'.22 Another petition, from 18 undersigned lessees and station managers, was more frank about the fact that a state of guerrilla warfare existed in the interior districts, and that a Native Police force was a necessary means of confronting 'native offenders' on their own terms: 'A great area of said country is composed of ranges, hills, and rough ground quite inaccessible to mounted men, and to dislodge or capture native offenders from these fastnesses - to which they retreat after they have committed any depredations they require to be met with equal cunning and strategy, and this would obtain by

14. Austin 1992: 11.

15. Mulvaney 1989: 40.

16. Willshire (1888) refers extensively to trouble with cattle killing at the Anna's Reservoir, Glen Helen, Owen Springs and Undoolya stations in the early 1880 s.

17. South Australian Parliamentary Papers, 53/1884; 170/1885. See Austin 1992: 17-19.

18. Willshire to Besley, 17 September 1884, Far Northern Division journal, SAPHS 000319.

19. Petition to the Chief Secretary, 14 July 1884, GRG 24/6/1480/1884.

20. Gordon to Peterswald, 13 October 1884 , GRG 5/2/828/1884.

21. 14 July 1884 , GRG $24 / 6 / 1480 / 1884$.

22. 14 July 1884 , GRG $24 / 6 / 1480 / 1884$. 
employing Native trackers. ${ }^{23}$ Such petitions for a Native Police force were also clear that, in terms of the rule of law, 'the Commanding trooper [would] have to exercise discretionary power - there being but few opportunities of cooperation such as are possible nearer civilisation southwards' ${ }^{24}$ In more than one of the pastoralists' petitions, Mounted Constable Willshire was recommended as such a force's commander. Regarded as already 'having been especially energetic and successful ${ }^{25}$ since his arrival in the Centre in 1882, and already 'possessing the confidence of all the settlers in the vicinity,' he was urged as 'the most suitable man' ${ }^{26}$

That a Native Police force would service the interests of pastoral security and expansion was a perception unambiguously shared by police administrators. Recommending the establishment of a Native Police force in the Centre in August 1884, Besley imagined that it 'could then patrol to the various stations and the sight of them would keep the Blacks in check - They could also meet the Queensland Police occasionally - and thus open up the country lying to the east of Barrows Creek to the Herbert River, where the country is very good. ${ }^{\prime 27}$ The Commissioner of Police equally acknowledged the need for enhanced police protection in the interior against the depredations of the natives', and assured his petitioners that the matter was under the consideration of the Government. ${ }^{28} \mathrm{He}$ also concurred with the suggestion that Willshire was 'very well qualified to be the leader of a party for this purpose'. ${ }^{29}$ Despite some administrative cautiousness about the precedent for 'unfavourable comment' that Native Police violence had accrued in Queensland, ${ }^{30}$ a Native Police force for the central Territory was authorised and established before the year's end, with Willshire in charge.

At the same time, as the missionaries at Hermannsburg had witnessed, Aboriginal people also required protection from the settlers, and - at least in theory - this recognition was entered into the documented discussion of the Native Police force's role. On 30 December 1884, a month after the Native Police force was authorised, the Protector of Aborigines Edward Hamilton wrote to the Commissioner of Crown Lands, reminding him of the economic as well as the moral benefits of gaining Aboriginal people's goodwill in the Centre. Enclosing a letter he had received a week previously from the Hermannsburg missionary Reverend Schwartz, expressing concern for the ill treatment of Aboriginals, ${ }^{31}$ Hamilton urged

the desirability of some steps being taken to protect these Aborigines from arbitrary and oppressive ill treatment at the hands of European settlers and their employees. There is little doubt but acts of this nature frequently occur and they

23. Willoby and 17 others to the Chief Secretary, 2 October 1884, GRG 24/6/2479/1884.

24. Murray, for the Barrow Creek Pastoral Co., to the Chief Secretary, 23 October 1884, GRG 24/ $6 / 2423 / 1884$.

25. Willoby and 17 others to the Chief Secretary, 2 October 1884, GRG 24/6/2479/1884.

26. Murray for the Barrow Creek Pastoral Co., to the Chief Secretary, 23 October 1884, GRG 24/ $6 / 2423 / 1884$.

27. Besley to Peterswald, 4 August 1884, GRG 24/6/1480/1884.

28. Peterswald to Gordon, 15 October 1884, GRG 5/9/1884.

29. Peterswald to the Chief Secretary, 29 October 1884, GRG 24/6/2423/1884.

30. See Wilson 1996: 66 .

31. Schwartz to Hamilton, 24 December 1884, Far Northern Division journal, SAPHS 000319. 
tend to establish ill feeling, and lead to outrages on both sides involving the Government in a costly and inglorious struggle with the Blacks, who if they were treated with a little more justice and forbearance would doubtless live amicably with and prove of much use to the pioneer settlers of these remote localities. ${ }^{32}$

He suggested that police presence in the interior be adequately resourced and that 'more frequent Police patrols be made through these districts' so that Aboriginal people, as well as settlers, would receive the law's protection. ${ }^{33}$ Sub Inspector of Police Besley responded with the reassuring comment that 'when the Native Police have been fairly established at the Alice Springs a continual patrol shall be kept up ... [which] will have the effect I am sure of keeping the Europeans, as well as the Blacks in check' ${ }^{34}$

In an ideal sense, then, the Native Police force's function was to provide a 'check' on both Aboriginal and European 'outrages'. It is unlikely, though, that such statements had anything other than a rhetorical function. As Queensland's example had already shown, the Native Police force had not so much a peace-keeping as a paramilitary function that was specific to frontier conditions, and that was directed entirely against Aboriginal 'cattle killers'. That this was broadly understood, both by the pastoralists who petitioned for the force's establishment and by the police administration that responded to them, is indicated by the terms on which the Native Police force was established and resourced.

It is also indicated by the extended freedoms for anticipatory policing that were granted to the Native Police force some three years after its establishment. Hitherto, police patrolling powers were limited to responsive measures, and the Native Police force did not have the freedom to take anticipatory action. However by 1887 , with the slow but gradual expansion in settlement, pastoralists were again petitioning the South Australian government for police 'to have liberty to patrol the district at any time, by this means they could pop in on [the Natives] when least expected' ${ }^{35}$ In an open letter to the press this same petitioner, the owner of Tempe Downs station, stated his sense of affairs more directly:

Are we, as stockowners, justified in instructing our managers and men to ruthlessly shoot these natives... We are not allowed to do this and rightly too. But what are we to do? ... One of three things must come about, \& that right speedily.

1. we must leave the country \& dispose of the stock that are left.

2. we must take the law into our own hands \& dispose of the natives as opportunity offers.

3. or we must have proper police protection to successfully carry on the development of the interior. ${ }^{36}$

Asked for his response, Willshire argued that expanded rights of the Officer in Charge of Native Police to freely patrol any region 'where the blacks are nearly always

32. Hamilton to the Commissioner of Crown Lands, 30 December 1884, Far Northern Division journal, SAPHS 000319.

33. Hamilton to the Commissioner of Crown Lands, 30 December 1884, Far Northern Division journal, SAPHS 000319.

34. Besley to Peterswald, 19 January 1885, GRG 5/2/61/1885.

35. Chewings to Peterswald, November 1887 , GRG 5/2/631/1887.

36. Chewings, draft 'Letter to the Editor', 9 November 1887, GRG 5/2,631/1887. 
doing something wrong ... would give more satisfaction than the usual way of waiting ... untill a report came re some offence' ${ }^{37}$ The request for expanded police patrolling freedoms was granted, as were additional resources for the Native Police force. ${ }^{38}$ It was clear, then, that the frontier officers who patrolled with the Native Police were not called upon to honour an administrative rhetoric about monitoring European as well as Aboriginal 'outrages'. Rather, their role was to respond to - and, from 1887, anticipate - the needs of the pastoral industry in enforcing Aboriginal subjugation.

\section{Writing the patrols}

Just three weeks before Besley rhetorically stated that continual police patrols would keep 'the Europeans, as well as the Blacks in check', Mounted Constable Erwin Wurmbrand wrote to him from the Alice Springs police station with an official report of a patrol he had just completed into the western MacDonnell Ranges, in pursuit of Aboriginals implicated in a recent attack on three employees at Glen Helen station. His report indicates, both in a cultural and a tactical sense, a general view that a state of localised warfare existed between the police and Aboriginal people.

The patrol lasted three weeks, and the party included two settlers, four Native Police officers, and eleven horses. Wurmbrand's report of their expedition proceeds as follows. Hearing at Glen Helen that men involved in the attack were camping nearby at Hermannsburg, the police party surrounded the mission station's camps and, moving just before daybreak, followed Wurmbrand's instructions 'to close circle gradually and clear all the wurleys of their inmates regardless of age or sex' ${ }^{39}$ Three men suspected of involvement in the Glen Helen attack were arrested and chained together by the neck, and a march with the prisoners was begun back to Glen Helen. They followed the Finke River to a point where

several gullies intercept the chain of hills, one of which the prisoners selected as the most suitable to attempt and possibly effect an escape.- At $6 \mathrm{pm}$ we reached the above mentioned place, and there the prisoners, who during the whole journey had continually been conversing in an undertone - made a sudden rush for the rocks.

Recognising 'the futility of my attempt at recapture' Wurmbrand ordered the party to fire: 'Prisoners are dead.' The police party continued its search for more offenders to the north-west, around Mount Sonder. On the fourth day, they tracked to an Aboriginal camp. 'A cloudy sky and a slight breeze favoured my further approach to reconnoitre and I found the camp situated in a rough gully inaccessible on horseback, the wurleys as usual widely scattered. It was nigh on day break when we cautiously facing the wind crept on the camp.' The police party had prepared for a silent approach by dismounting and removing their boots, but despite their caution, the camp was alarmed: 'the trackers instantly called on them in their own language to surrender but a flight of spears was the savages reply.' In the resulting volley of bullets, four Aboriginal men were shot dead; 'the rest seeing their leaders fall immediately made for rocks, our bare feet, sorely tried by sharp stones \& Spinifex, favoured the fugitives, who were

37. Willshire to Besley, 21 November 1887, GRG 52, 631/1887.

38. GRG 5/2/631/1887.

39. Wurmbrand to Besley, 26 December 1884, Far Northern Division journal, SAPHS 004651. 
soon out of reach \& sight.' The police party burned the camp's huts and goods, and would have continued the search for further offenders, but abandoned the action 'on a/ c of our scanty supply of very inferior rations having completely run out'. The party returned to Alice Springs with a tally of seven Aboriginal deaths and no successful arrests. Wurmbrand concluded his report with the view that if more police were available to continually patrol the MacDonnell and neighbouring ranges, the blacks 'would soon be pacified. At the present they are well aware that a white man is no match for them in their rocky haunts. ${ }^{40}$ Two days after responding to the Protector of Aborigines' suggestion for more police patrols in the interests of Aboriginal as well as European protection, Besley forwarded this report from Wurmbrand to the Commissioner of Police, who perused and returned it. It was filed in the first days of $1885 .{ }^{41}$ In the last days of that year, Wurmbrand wrote again to Besley requisitioning Native Police supplies for the year to follow, including the 'absolute requirement' of revolvers, 'as a rifle in a mele ... is a great hindrance'. ${ }^{42}$ In a climate of economic curtailment in the colony, he also justified the important role of the Native Police:

Hitherto the native Police has done their work to the advantage of the settlers, having checked the outrages by Natives to a great extent ... I also trust that my commanding officers are satisfied as to the efficiency of the Native Police Force, although they may have experienced annoyance by unfounded \& unjustified reports charging us with unnecessary severity. - I acknowledge now, as I have done in my previous reports, that sometimes stringent measures had to be adopted, measures which may seem even harsh to people, who do not know what the savages up here of capable of doing. ${ }^{43}$

Although he drew attention to 'the extraordinary form of the requisition', the Commissioner of Police approved it in the new year. ${ }^{44}$

Much more than Wurmbrand, Willshire was a prolific writer, and he expressed both his personal and his professional views on frontier policing openly and expansively. For Willshire, civic duty was clearly and inextricably tied to the project of pastoral expansion and, through that, to the project of new nationhood. In this sense, Willshire was not an imperialist: he was, he wrote, an 'Australian native', a man 'born under the Southern Cross' ${ }^{45}$ He clearly identified himself, then, as a member and forerunner of the nation-to-be which would find its imaginative fulfilment here, in the heart of the continent. His experiences as a police officer in the Centre - or at least his imaginative reconstruction of them - are documented in several books published between 1888 and 1896. A mixture of ethnography, memoir, political polemic and adventure romance fiction, these provide a fascinating supplement to his official police reports, and flesh out his identification with a potent form of nationalism that, from the 1870s, was becoming the theme of popular fiction. ${ }^{46}$ In the first of his books, The

\footnotetext{
40. Wurmbrand to Besley, 26 December 1884, Far Northern Division journal, SAPHS 004651.

41. Besley to Peterswald, 21 January 1885, Peterswald to Besley 26 January 1885, GRG 5/2/72/ 1885.

42. Wurmbrand to Besley, 27 December 1885, GRG 5/2/198/1886.

43. Wurmbrand to Besley, 27 December 1885, GRG 5/2/198/1886.

44. Peterswald to the Chief Secretary, 16 March 1886, GRG 5/2/198/1886

45. Willshire 1891: Preface.

46. See Dixon 1995.
} 
Aborigines of central Australia, he clarifies his sense of duty as a frontier policeman: he represented not so much 'the law' as the process of development, which would lead inexorably to 'the extension of pastoral enterprise and settlement'. ${ }^{47}$ Both his literary writings and his official police reports indicate that Willshire saw himself as stepping confidently into the transitional space of the Centre, imaginatively adopting the status of those earlier heroic figures of the colonial frontier, the explorer and the pioneer, but empowered by the law to oversee - more than that, to affect - the region's transformation through Aboriginal pacification. ${ }^{48}$

Possibly there is little in this that seems surprising. What is more surprising is the extraordinarily frank sense that there is indeed a frontier war to be won, which seeps through the official reports of his patrols. These reports were forwarded to the Sub Inspector of Police, circulated within the police administration, and filed. Three months before the establishment of the Native Police force, in August 1884, Willshire was required to undertake an expedition to Anna's Reservoir in response to the burning of the homestead and an attack on two station employees. His official report to Besley on this expedition is characteristic, both of his frank admission of the reality of frontier warfare, and of an assumed understanding that this reality framed - and in fact exceeded - the rule of law.

Although the report begins with lip service to the formal objective to 'try and arrest the principal offenders', it proceeds readily into a description of violent struggles waged and won. He describes how he and his party pursued tracks 'over range after range' until eventually, 'on the 7th day out, things began to look warm'. Finding a camp recently vacated, 'with five puppies and any amount of weapons', they 'burnt and smashed them all up and killed the dogs watered our horses at a rockhole and proceeded on'. When that night they tracked to an occupied camp, the police party's approach was planned around the best potential for unexpected attack:

3am saddled up quietly kept no fire that night and no talking but led the horses up to foot of range ready to attack camp at daylight we made a rush full gallop [up] some small hills and observed the natives running up with weapons in hand a bigger adjoining hill, Price and I to the front soon had 6 bailed up and our trackers telling them to drop their spears but they said the[y] would not and sent about a dozen 10 foot spears whizzing at us ... [I] went straight for [one] who turned neatly and struck me with his boomerang he ... was escaping when a bullet from a snider rifle brought him to the ground, after the affray was over I called the men together and enquired what each had done when one of the trackers told me he had shot Slim Jim dead this was good news to me knowing that Slim Jim was the leader at the burning of the Station and also the principle ringleader of cattle killers. $^{49}$

The impression from this scene that the battle is against a dangerous and known enemy is belied by the next, in which it is clear that the police party's attack is against a whole (now ransacked) social community: 'I believe there were about 100 women and children around us when the fight was over all yabbering away at the same time I

47. Willshire 1888: 8 .

48. In doing so, he later writes, 'I achieved an infamous eminence which I never deserved in doing duty assigned to me amongst murderous aborigines' (Willshire 1896:5).

49. Willshire to Besley, 17 September 1884, Far Northern Division journal, SAPHS 000319. 
marched the whole lot down off the range and made them show where the water was.' As the leader of the conquering party, however, Willshire is mindful of chivalry: 'all my party were manly fellows and treated the Lubras and piccaninnies with kindness we then discharged them and returned to water our horses' ${ }^{50}$

Given that this is his official police report, Willshire shows a strikingly operatic taste for the drama of battle and its success. Reporting on the pursuit of more cattle killers during the same expedition, he writes: 'as soon as they saw us they ran through the Mulga scrub towards the Reynolds Range we took to them as fast as we could ... on this occasion the notorious cattle killer Jimmy Mullins was brought down by a Spencer rifle the rest narrowly escaped'. Two days later on 7 September 1884,

another batch of niggers was seen amongst them was "Boko" for whom I held a warrant my tracker tried to take this fellow alive but I think "Boko" could handle his waddy too well ... the tracker was in a terrible rage at being got at by a wild nigger so he levelled his rifle and "Boko" came toppling down from rock to rock and landed at the trackers feet. ${ }^{51}$

Despite these successes with the rifle, Willshire's sense that he is engaged in a frustratingly difficult form of frontier warfare is suggested by his grudging respect for his enemies' elusiveness: 'I may here state that the natives both at Anna's Reservoir and Owen Springs are getting worse instead of better in my opinion they don't care about death a bit then [take] refuge in the big high ranges and without a fellow [being] most particularly smart he wont even be able to get a shot at them ${ }^{\prime}{ }^{52}$

The personal significance such campaigns held for Willshire is expressed in these official police reports to his superior, whose sympathetic ear he assumes. In September 1884, the same month as his Anna's Reservoir expedition, he undertook an expedition to Undoolya station in pursuit of cattle killers. His report on this patrol offers, again, a surprisingly indiscrete view of the pressing need to 'get' more natives than has hitherto been achieved, as well as his own personal success in doing so. 'I desire to draw the Inspectors attention to this that there have been cattle stations up here this last 8-9-10 years and the natives have killed hundreds of cattle very few natives have been got at and I ... have always got at the natives I wanted even in their pet ranges ... nothing stops me but the want of water and that seldom occurs for when in hot pursuit after niggers you are bound to fetch water. I have been successful I know but I had to work hard for it. ${ }^{53}$

The report of this particular expedition records his pursuit of tracks along Trefeena Creek until coming upon 'natives close to a big range'. Finding themselves under a volley of stones, spears and boomerangs, Willshire and a tracker 'got behind big rocks and now and again got a shot at them'. Three Aboriginal men were shot dead and four others wounded, according to his report. The rest 'got away from us'. Who is to say whether or not these men were the cattle killers Willshire sought? The question seems to be irrelevant in light of his sense that the whole region itself is at stake, and that his duty in making it secure is to undertake a symbolically powerful series of

50. Willshire to Besley, 17 September 1884, Far Northern Division journal, SAPHS 000319.
51. Willshire to Besley, 17 September 1884, Far Northern Division journal, SAPHS 000319.
52. Willshire to Besley, 17 September 1884, Far Northern Division journal, SAPHS 000319.
53. Willshire to Besley, 29 September 1884, Far Northern Division journal, SAPHS 000319. 
punitive campaigns. This is intimated by Willshire's anticipation of campaigns yet to come: 'now the next thing', he writes to Sub-Inspector Besley, 'is the Owen Springs country the natives are now killing valuable horses this I deem unbearable and for it they shall be punished'. ${ }^{54}$ This report concludes with his request to organise and lead the Native Police force, if and when it should be established. '6 trackers and one smart man who knows how to work them and knows the country ... would soon give satisfaction to all ... should a native force be organised I trust that the Inspect. will consider what I have done and my experience amongst the natives though I have only been here 2 years. ${ }^{55}$

Besley made his approval of Willshire's work clear when he forwarded this report of the Undoolya expedition to the Commissioner of Police with the comment that '[Willshire's] perseverance and courage well deserves our commendation' ${ }^{56}$ Despite Peterswald's rather dry rejoinder that 'this would have been a much more interesting narrative if the writer had not put himself so prominently forward', 57 Willshire was duly appointed Officer in Charge ${ }^{58}$ and within the month had completed his first formal patrol in that role. Willshire was accompanying six Native Constable recruits to Palmerston (Darwin) in December 1884 when he was directed to respond to cattle killing in the region of Powell's Creek and issued with warrants for four known offenders. The outcomes of that expedition are documented in a telegraphed report to Besley. No arrests were made but the deaths of three Aboriginal men, shot resisting arrest, are recorded. ${ }^{59}$ Willshire concludes this report with a comment on the success of this, his first expedition as Officer in Charge of the Native Police: 'The trackers worked well, and their obedience to instructions was conspicuously observed'. ${ }^{60}$ Having fulfilled his responsibility to commit those Native Constables to the command of Inspector Foelshe in Darwin, Willshire returned to Alice Springs where he recruited the Native Police force that would patrol the Centre over the coming years.

Neither the Sub-Inspector nor the Commissioner of Police saw anything to reproach in the police reports they received from the Centre through the $1880 \mathrm{~s}$. In fact there is every indication that Besley, as the immediate recipient of these reports, considered these Constables in outlying regions to be doing an excellent job. ${ }^{61}$ More locally at Hermannsburg, however, the missionaries were more sceptical, and did not

54. Willshire to Besley, 29 September 1884, Far Northern Division journal, SAPHS 000319.

55. Willshire to Besley, 29 September 1884, Far Northern Division journal, SAPHS 000319.

56. Besley to Peterswald, 28 October 1884, Far Northern Division journal, SAPHS 000319.

57. Peterswald to Besley, 14 November 1884, Far Northern Division journal, SAPHS 000319.

58. Peterswald to Besley, 14 November 1884, SAPHS 920/1884.

59. Willshire (by telegraph) to Besley, forwarded to Peterswald, 10 December 1884, SAPHS 803$1006 / 1884$.

60. Willshire (by telegraph) to Besley, forwarded to Peterswald, 10 December 1884, SAPHS 803$1006 / 1884$.

61. Besley to Peterswald, 28 October 1884, SAPHS 803-1006/1884. Besley also lent his support to Mounted Constable Samuel Gason, who had led the 1874 punitive expedition in response to the Barrow Creek telegraph station attack that resulted in potentially dozens of Aboriginal deaths. When Gason retired from the police force and applied for a government billet, Besley wrote a recommendation affirming that 'he was an excellent and courageous Police officer much respected by officers \& men' (18 September 1884, Far Northern Division journal, SAPHS 000319). 
forget that the presence of the police in the interior was intended, at least in theory, to protect Aboriginal people as well as pastoral interests. Within six months of the establishment of the Native Police force under Willshire, Reverend Kempe wrote to the Protector of Aborigines complaining not so much about the violence of the settlers, as his colleague Schwartz had done the previous year, but about that of the police. Responding to Hamilton's assurance that 'a police force at Alice Springs shall be established to keep both the Europeans and the Blacks in check', Kempe wrote: 'Whether from this measure shall arise any good for the natives is rather doubtful as long as there is nobody to control the actions of the police troopers. The only difference will be that the natives are now shot down by policemen whilst before the other whites did it. ${ }^{62}$ In his letter he raises the case of the three chained Aboriginal prisoners shot dead en route to Glen Helen by 'a police trooper' (Wurmbrand) five months before. Kempe visited the site where the bodies still lay and expressed disbelief at Wurmbrand's reported events:

the natives informed us the 3 natives were shot down by the whites. We went there \& convinced ourselves from [of] the truth of this statement. Now we expected directly the whites would say they tried to escape \& so they did when we asked them. But who can believe it? Who can believe that they broke the strong chain? Who can further believe that escaping they kept together? One should think, if it happened that they got unfastened the chain, they would run away in every direction, but the bodies were lying on one heap \& exactly as they were tied together. ${ }^{63}$

Kempe's letter was forwarded by Hamilton to the Commissioner of Police, who sent it back to Besley for investigation. Besley sought further information from Mounted Constable Daer, who was stationed at Charlotte Waters and had spent some time patrolling with Wurmbrand. Daer's comments cast no new light on the matter: 'I know nothing of the alleged shooting of blacks by a police trooper, during my residence in the Interior when my duties have brought one in to collision with the natives I have always tried to avoid taking violent measures'. ${ }^{64}$ The correspondence was forwarded to Wurmbrand, still at Alice Springs police station, who respectfully directed the Inspector back to his original report. ${ }^{65}$ The case rested there.

As Daer's comments suggest, other Mounted Constables who worked the Centre in this period did not establish the same kind of reputation for violence as did Willshire and Wurmbrand. For instance, as Mulvaney has pointed out, Constable Daer and his colleague Ernest Cowle (who was posted to the Centre not long before Willshire's departure) seem to have preferred instilling fear of the whip rather than of the rifle as their method of remote policing. ${ }^{66}$ In the last year of the century, Cowle wrote to Baldwin Spencer, for whom he had become an ethnographic collector, 'I am not advocating shooting, for a moment, in the so called good old style, but they should be made to respect the law of the Land that has been taken from them, and it would be

\footnotetext{
62. Kempe to Hamilton, 13 April 1885, Far Northern Division journal, SAPHS 000319.

63. Kempe to Hamilton, 13 April 1885, Far Northern Division journal, SAPHS 000319.

64. Daer to Besley, 4 June 1885, Far Northern Division journal, SAPHS 000319.

65. Wurmbrand to Besley, 5 June 1885, Far Northern Division journal, SAPHS 000319.

66. Mulvaney et al. 2000: 35. Also Daer to Besley,11 August and 6 September 1887, GRG 5/2/ $475 / 1887$.
} 
better for them. ${ }^{67}$ At the same time, it would be a mistake to regard Willshire and Wurmbrand simply as aberrations of a more benign frontier culture. To recall Robert Warbarton's pragmatic acknowledgement of frontier conditions, a potential phase of conciliation might come once 'the blacks knuckle under - but not before' ${ }^{68}$ The huge regions under isolated patrol meant that civic officers of Willshire's or Wurmbrand's temperament and sense of duty, backed by the law and legitimately in charge of weapons, supplies and men, had few limits on their authority, which during the phase of subjugation was significantly unfettered by the infrastructure of bureaucracy.

\section{The shifting frontier}

By the turn of the last decade of the nineteenth century Willshire's autonomy was on the wane, along with the initial thrust of the unstable frontier. The era of aggressive Aboriginal pacification in the Centre was gradually moving into an era of anthropological survey, marked by events such as David Lindsey's Elder Scientific expedition in 1891 and Baldwin Spencer's Horn Expedition in 1894. More directly, Aboriginal people were now proving to be indispensable to the pastoral industry, as the 1891 visit of the Pastoral Lands Commission found. ${ }^{69}$ In the shifting climate of the new decade, Willshire's activities came under a new degree of surveillance. After repeated complaints by the missionaries at Hermannsburg, a government inquiry was held in 1890 into policing measures in the Centre, although in their report of that inquiry, the commissioners found no cause to reproach the police. ${ }^{70}$ But in February 1991, Willshire directed his Native Constables to shoot dead two Aboriginal men close to the Tempe Downs head station, and subsequently burn the bodies. He held no warrants for their arrests. Willshire's report on the episode was received not by Besley but by the recently appointed Attorney General, Robert Homburg, who was disconcerted by inconsistencies in it and ordered an inquiry into the case. In the years since Willshire had been forwarding his patrol reports, this was the first time an inquiry was to be held into Aboriginal deaths under his command. At the end of the inquiry, in April 1891, Willshire was arrested on a charge of wilful murder. He was tried in July, but acquitted. On his reinstatement into the force he was keen to return to the Centre, but at the Commissioner of Police's behest, he was eventually posted much further north, to the Victoria River. Arguing for Willshire's transfer to the Northern Territory Police in early 1893, Peterswald commented that it would be advisable to 'give him a station in the Bush on the first opportunity that offers, as though a source of trouble in a station down country I believe he would be a useful man in the interior' ${ }^{71}$ The culture of the frontier in the Centre, clearly, had changed, but Willshire could still be considered the man for the farflung countries. The potential ironies of the discretionary rule of law that had pertained through the 1880 s were not lost on fellow 'Northerners'. After Willshire's murder trial, a supporter wrote: 'The Government employ M.C. Willshire for a certain duty, they

67. Mulvaney et al. 2000: 128 .

68. Warburton to Gordon, 22 May 1890, GRG 1/1/395/1890

69. Report of the Pastoral Lands Commission, South Australian Parliamentary Papers 1891, vol. 3 , no. 33.

70. Report of Swan and Taplin, 30 September 1890, South Australian Parliamentary Papers, no. $148: 1-3$.

71. Peterswald to Saunders, 30 March 1890, SAPPHS COP 304/1893. 
supply him with revolvers, rifles, and ammunition in abundance, and ... [when] these weapons [are] used for the benefit of the country the officer in charge becomes a felon. $^{72}$

What is notable is not just that officers of the law like Willshire and Wurmbrand would regard the frontier as a special zone of police/Aboriginal warfare. It is also that they were enabled, indeed resourced, to do so by a far-distant police bureaucracy which shared with most of colonial culture an orthodox understanding that frontier conditions were both difficult and different from those of the settled districts, and which accordingly allowed for a discretionary flexibility in the rule of law. This was so in spite of the administration's awareness of the notorious reputation of earlier Native Police forces in Queensland and New South Wales and a commensurate recognition (at least in theory) of Aboriginal rights to legal protection. It held true as long as that flexibility did not force itself unduly on the notice of the authorities (as it did eventually in Willshire's case) to the degree of requiring intervention.

The first significant sign of how a discretionary policing procedure would operate in the South Australian controlled Territory came with conflict in the north, on the Roper River in 1875, where a telegraph station master was killed and two others were wounded. Paul Foelsche, the Darwin-based Inspector of Police, gave instructions to the punitive police party to identify and capture anyone belonging to the guilty parties, and also included a clause which allowed for circumstances that strictly legal regulations could not accommodate: 'I cannot give you orders to shoot all natives you come across but circumstances may occur for which I cannot provide definite instructions. ${ }^{73}$ A discretionary understanding of legal form is also implicit (though, no doubt, not intended) when Besley forwarded to Peterswald the report of Willshire's patrol to Undoolya (three Aboriginal men shot dead, four wounded, no arrests) with the comment that 'his perseverance and courage well deserves our commendation'. ${ }^{74}$ The same understanding is implicit when, a few weeks later, he forwarded the report of Willshire's patrol to Powell's Creek (three shot dead, no arrests), with the notation that Willshire had had instructions 'to act as the law provided' ${ }^{75}$ When Willshire published his last book The land of the dawning in 1896, he summed up his frontier policing career in these terms:

I am proud to be able to submit to paper that the Government at the time told me as the officer of police parties to go out and do as the law provides in such cases. I worked hard ... and now I say, "All's well that ends well". 76

\section{The central Australian frontier in social memory}

A question that remains is how these events have been remembered in continuing social memory. In contemporary histories of frontier conflict, Willshire's and Wurmbrand's names arise as exemplars of a culture of the acceptable violence that pertained in late colonial central Australia. ${ }^{77}$ This is not the only form of remembrance, however.

\footnotetext{
72. Tom Fowler, 25 July 1891, published as 'Letters and Extracts from Newspapers' in Willshire 1895: 62.

73. Foelsche to Montague, 19 July 1875, cited in Austin 1992: 15.

74. Besley to Peterswald, 28 October 1884, Far Northern Division journal, SAPHS 000319.

75. Besley to Peterswald, 10 December 1884, SAPHS 803-1006/1884.

76. Willshire 1896: 20.
} 
Willshire of Alice Springs, a biography paying glowing tribute to the work performed and the hardships endured by Willshire and the colonial police, was published by Austin Stapleton in 1992. In the 1980s, the decade which commemorated Australia's bicentenary, Willshire's story was twice revived as a feature subject for popular newspaper articles, which appeared under such headings as 'Historical feature' and 'This was Australia', and which brought back the colonial frontier as a theme of historical reminiscence. Though mindful of the unacceptability of violence for contemporary audiences, ${ }^{78}$ these feature articles are noticeable for the service to which this violent history is put in nostalgically recalling a colonial romance with the country. In a feature article titled 'Rebel mountie tried to tame frontier', published in the Sydney Sun in 1980, a uniformed Willshire gazes from the page over the span of a hundred years, and his history's institutionalised violence is subsumed to the recreation of a frontier adventure narrative which Willshire himself might have written:

In charge of a frontier police post, the adventurous 27 year old rebel had found his niche. Despite a love of notoriety and exaggeration, [he] won respect for his personal courage and attention to duty ...

He was kept busy investigating settler[s'] complaints against aggressive tribesmen determined to drive out the white men and their cattle. Some holdings were abandoned. A typical patrol with native horseboys and packhorses took about three months to cover 3,000 kilometres of rugged wilderness ... Eternal vigilance was necessary to counter ambush and dawn attacks.

Settlers took the law into their own hands, though deploring the need. Not a man among them went unarmed. Willshire was appointed to train a native police force. The first batch of six recruits learnt the care of equipment and horses, and to shoot accurately, and the one-time rebel turned them into useful, well-disciplined men. ${ }^{79}$

Willshire's story has also entered the genre of tourist magazines that today invite 4-wheel-drive explorers to discover the secrets of the Centre and its formerly inaccessible frontiers. Owen Springs and Undoolya Stations, formerly sites of Willshire's violent patrols, are now advertised for off-road and quad bike adventure tours, and Willshire's former police camp at Boggy Hole on the Finke River is 'one of the most popular remote camps in the area' ${ }^{80}$

The sources for some of these contemporary recollections are probably Willshire's own books, which recreate the once-violent frontier as a theme of adventure narrative. His official reports tell a similar but less glorified tale, and may, in fact, invite an intention not to remember but rather to forget. Copies of his and Wurmbrand's reports of their patrols with the Native Police, and Besley's receipts of them, are contained in a journal of correspondence for the police's Far Northern Division between 1884 and

77. Some examples are Merlan 1978: 83; Mulvaney 1989: 128; Petersen 1989: 59-62; Rose 1991; Austin 1992: 22; Kimber 1997: 41-64.

78. As one piece puts it, 'William Willshire is not much read today because the exultation with which he gloated over the slaughter of Aborigines would scarcely appeal to late 20th century readers.' Daily Mirror 20 June 1985: 32.

79. Sydney Sun, 5 February 1980: 38.

80. 4X4 Australia, March 2004: 94-9. The Boggy Hole police station ruins are described as ta stark reminder of a violent past', and interestingly, Willshire is described as being charged for the murder not of two but 'of six Aborigines'. 
1890, now held in the South Australian Police Historical Society archives. Attached inside the front sleeve of this journal is a note, dated 1972, from a reader who thanks the journal's donor for its use, and offers comment on its contents. The reader expresses concern for the journal's future, partly because many such original documents no longer exist, but partly because of the social pain that exposure of the contents could cause: 'There is one extract which refers to the police shooting of prisoners - how would that be in print? ... some of the information in [old Journals] is not fit to be put on public display. ${ }^{81}$ This reader's concerns raise, in particular, the two questions with which this discussion began: how are events such as these told, and how are they remembered? Underpinning these questions is perhaps another, one that resonates in much of the debate around Australia's history of frontier conflict. It asks not only what happened, or how those things are told and remembered. It also asks what, in the service of remembrance, is forgotten?

\section{Acknowledgement}

This paper arises from and is indebted to a larger collaborative study of William Willshire, in progress with Robert Foster of the School of History and Politics, University of Adelaide.

\section{References}

\section{Primary sources}

Daily Mirror 20 June 1985: 32.

'Pleasure central' in $4 x 4$ Australia, March 2004.

'Rebel mountie tried to tame frontier' in Sydney Sun 5 February 1980: 38.

South Australian Parliamentary Papers 1890-91.

South Australian Police Historical Society archive (SAPHS) Commissioner of Police files; Far Northern Division journal.

State Records of SA, Attorney General's office correspondence files (GRS 1/1); Commissioner of Police's office correspondence files (GRG 5/2); Chief Secretary's office correspondence files (GRG 24/6); Aborigines Department files (GRG 52).

'Territory trooper gloated over butchery of blacks' in Daily Mirror, 20 June 1980.

\section{Secondary sources}

Attwood, Bain and SG Foster (eds) 2003, Frontier conflict: the Australian experience, National Museum of Australia, Canberra.

Austin, Tony 1992, Simply the survival of the fittest: Aboriginal administration in South Australia's Northern Territory 1863-1910, Historical Society of the Northern Territory, Darwin.

Broome, Richard 1988, "The struggle for Australia: Aboriginal-European warfare 1770-1930' in M McKernan and M Browne (eds) Australia: two centuries of war and peace, Allen \& Unwin, Canberra: 92-120.

Clark, Ian 1996, Scars in the landscape, Aboriginal Studies Press, Canberra.

81. Note dated 1 October 1972, pasted inside the cover of the Far Northern Division journal, SAPHS 000319. 
Connor, John 2002, The Australian frontier wars 1788-1838, University of New South Wales Press, Sydney.

Dixon, Robert 1995, Writing the colonial adventure: race, gender and nation in AngloAustralian popular fiction 1875-1914, Cambridge University Press, Cambridge.

Evans, Raymond and Bill Thorpe 2001, 'Indigenocide and the massacre of Aboriginal history,' Overland 163, Winter 2001: 21-39

Foster, Robert, Rick Hosking and Amanda Nettelbeck 2001, Fatal collisions: the South Australian frontier and the violence of memory, Wakefield Press, Netley.

Headrick, Daniel 1981, The tools of empire: technology and European imperialism in the nineteenth century, Oxford University Press, New York.

Kimber, Richard 1997, 'Genocide or not? The situation in Central Australia 1860-1895' in Colin Tatz (ed) Genocide perspectives I: essays in comparative genocide, Centre for Comparative Genocide Studies, Sydney: 33-65.

Merlan, Francesca 1978, "'Making people quiet" in the pastoral north,' Aboriginal History 2(1): 71-102.

Mulvaney, DJ 1989, Encounters in place: outsiders and Aboriginal Australians 1606-1985, University of Queensland Press, St Lucia.

Mulvaney, DJ with Alison Petch and Howard Morphy 2000, From the frontier: outback letters to Baldwin Spencer, Allen \& Unwin, St Leonards, NSW.

Peterson, Nicolas 1989, 'A colonial image: penetrating the reality of the message' Australian Aboriginal Studies 2: 59-61.

Reid, Gordon 1990, A picnic with the natives: Aboriginal-European relations in the Northern Territory to 1910, Melbourne University Press, Melbourne.

Rose, Deborah Bird 1991, Hidden histories: black stories from Victoria River Downs, Humbert River and Wave Hill stations, Aboriginal Studies Press, Canberra.

- 2003, 'Oral histories and knowledge' in B Attwood and S Foster (eds) Frontier conflict: the Australian experience, National Museum of Australia, Canberra: 120-31.

Shepherd, Shirley 1996, 'The significance of the overland telegraph line' in Journal of Northern Territory History 7: 41-46.

Stapleton, Austin 1992, Willshire of Alice Springs, Heperian Press, Victoria Park WA. Willshire, William 1888, The Aborigines of central Australia D Drysdale, Pt Augusta.

— 1891, The Aborigines of central Australia, 2nd edn, CE Bristow, Adelaide. 1895, A thrilling tale of real life in the wilds of Australia, Freason \& Brother, Adelaide.

- 1896, The land of the dawning: facts being gleaned from the cannibals of the stone age, WK Thomas, Adelaide.

Wilson, Bill 1996, 'The establishment of and operations by the Northern Territory native police between 1884 and 1891', Journal of Northern Territory history 7: 65-73.

2000, A force apart: a history of the Northern Territory police 1870 to 1926, Peacock Press. 